\title{
Machine-Learning Methods for Assessing Dynamic Resistance of Existing Bridge Structures Subjected to Mining Tremors**
}

\begin{abstract}
This paper demonstrates the results of research studies aimed at creating a model that allows to determine the resistance of existing bridge structures to the impact of mining tremors. A database (created by the author of this article) of the dynamic resistance of reinforced concrete bridge structures subjected to seismic excitations commonly occurring in the Legnica-Głogów Copper District (LGOM) formed the basis for the analysis. The dynamic resistance of each structure contained in the database was expressed as the limit values of the acceleration of ground vibrations that may be carried by a given structure without compromising its safety. The study was carried out using the Support Vector Machine (SVM) method in a Support Vector Regression (SVR) approach as well as an Artificial Neural Network (ANN). The models were compared in terms of the quality of the predictions and generalization of the acquired knowledge. This allows to select the most-effective method in evaluating the dynamic resistance of existing bridge structures.
\end{abstract}

Keywords: dynamics of structures, Machine learning, Artificial Neural Networks, SVM Support Vector Machine, mining tremors, dynamic resistance, Bridges

\footnotetext{
* AGH University of Science and Technology

** The article was prepared as part of the AGH statutory research No. 11.11.150.005
} 


\section{Introduction}

Preventive measures in the scope of surface protection against the damaging effects of underground mining exploitation calls for an assessment of the resistance of structures comprising the infrastructure in a specific mining area. This problem not only applies to buildings but also to bridge structures. In addition to continuous surface deformations, there are mining tremors occurring in the Legnica-Głogów Copper District (LGOM) [4,17]. Numerous studies have proven that the dominant factor that poses a threat to the infrastructure in this area are paraseismic phenomena [e.g., 2,18]. The problem is particularly related to existing buildings constructed during the period when these phenomena were not taken into account during the design process.

This paper [12] presents a proposal for assessing the dynamic resistance of existing bridge structures to the impact of mining tremors. This procedure involves determining the margin of the load-bearing capacity of a given structure resulting from the assumptions adopted at the design stage, where additional effort on its load-bearing elements may be allowed in the event of a mining tremor. It allows us to determine the permissible values of the acceleration of ground vibrations at the location of the structure $\left(a_{g, d o p, V}\left[\mathrm{~m} / \mathrm{s}^{2}\right]\right.$ and $\left.a_{g, d o p, H}\left[\mathrm{~m} / \mathrm{s}^{2}\right]\right)$ that can be carried by a structure without compromising its safety. In general, this approach can also be applied to structures such as steel or reinforced concrete industrial portal frame buildings.

If, however, it is necessary to define the dynamic resistance for a large number of objects, this procedure becomes ineffective. This is due to the fact that, in each case, it requires the construction of an FEM model, a determination of all load combinations taken into account at the design stage, and the static and dynamic analyses performed, all while taking into consideration the model response spectra for a specific area as well as the recording and analysis of the results obtained in the context of the criteria adopted for the assessment of resistance.

An additional problem that concerns the existing reinforced concrete bridge structures is a lack of precise information on the strength parameters, strength of reinforcement of the load-bearing components, or parameters reflecting the current friction in the sliding bearings. The criteria specified in [12] allow for the assessment of resistance in the absence of information on the compressive strength of the concrete, which is the building material of various elements of the load-bearing structure and the actual reinforcement of the elements. However, parameters such as the modulus of elasticity of the concrete and the coefficient of friction in the bearings must be determined to perform a numerical analysis. However, it is frequently the case that there is no design documentation; therefore, the information on these parameters is uncertain and results from in-situ surveys or studies. Thus, it is necessary to perform numerical simulations in many variants resulting from the random dispersion of these parameters [3].

In view of such a problem, the author found it reasonable to seek a more-effective method to assess the resistance of a large group of structures without the need for their individual analysis in accordance with the adopted resistance-assess- 
ment procedure. For this purpose, a database on the resistance of reinforced concrete bridge structures with a slab span system (in various geometrical and material variants) has been created based on multiple numerical Finite Element Analyses. Then, a Multiple Linear Regression (MLR) model was attempted to be built to estimate the determined permissible acceleration of ground vibrations $\left(a_{g, d o p, V}\left[\mathrm{~m} / \mathrm{s}^{2}\right]\right.$ and $\left.a_{g, d o p, H}\left[\mathrm{~m} / \mathrm{s}^{2}\right]\right)$. The performed analyses demonstrated that the relationships between the geometrical and material properties as well as the resistance are nonlinear, and the created MLR models were not sufficient for their correct description [11]. Therefore, the author sought methods that allowed for the nonlinear approximation of resistance expressed as the permissible acceleration of ground vibrations $\left(a_{g, d o p, V}\left[\mathrm{~m} / \mathrm{s}^{2}\right]\right.$ and $\left.a_{g, d o p, H}\left[\mathrm{~m} / \mathrm{s}^{2}\right]\right)$ in the domain of the geometrical and material parameters.

As a result, Machine Learning methods (ML) were introduced in the studies. An ANN (Artificial Neural Network) and SVM (Support Vector Machine) in a regression approach - SVR (Support Vector Regression) were tested. The paper presents the results of building models approximating the permissible values of the acceleration of ground vibrations $\left(a_{g, d o p, V}\left[\mathrm{~m} / \mathrm{s}^{2}\right]\right.$ and $\left.a_{g, d o p, H}\left[\mathrm{~m} / \mathrm{s}^{2}\right]\right)$ using these methods. The obtained models were assessed in terms of fit quality to the real data as well as generalizability.

The final model should replace the current procedure of determining the dynamic resistance for the range of types of structures for which it was created.

\section{Research Methodology}

Both Artificial Neural Networks (ANN) and Support Vector Machine (SVM) models belong to the group of Machine Learning methods (ML) [15]. The structures of these systems are very similar. In each, the information contained in the vector of input data $X^{T}$ is processed in parallel by all computational units (such as artificial neurons in the case of neural networks [13] and, in the case of SVM systems - properly defined kernel functions [1], [16]). Practically, the SVM model has a structure analogous to Radial Basis Function Neural Networks (RBF). The difference between them lies only in the acceptance of various criterion functions for learning [9].

In the case of neural networks, the determination of the synaptic weights between neurons is carried out in the process of minimizing an appropriately constructed criterion, which is a function of error between the real data and prediction of the model. Calculations are performed on a specified training set. In parallel, after each iteration, the network response for the data from the training set is compared with the results obtained on the additional validation set. This allows us to avoid overfitting the network, which leads to the loss of generalizability [9]. The created network is assessed on a test set. A comparison of the results for training and test sets allows us to assess the network for is generalizability. However, the selection of the number of neurons in the hidden layer is arbitrary, so it is necessary to test multiple networks in order to separate an optimal structure for a specific problem. 
In the case of SVM, the role of the weights in neural networks is performed by Lagrange multipliers. This is dictated by the adoption of a linear objective function that is different than in neural networks. This criterion is a compromise between the good fit of the SVM network to the learning data and generalization of the model. Finally, the problem is reduced to solving a quadratic optimization problem [9].

If the SVM method is used for regression tasks, it is required to arbitrarily accept three parameters: $C, \varepsilon$, and $\sigma$. These parameters occurring in the formulation of the criterion function represent the following, respectively: $C$ - the regularization parameter, determining the range of permissible values of the Lagrange multipliers; $\varepsilon$ - the range of the tolerance band; and $\sigma-$ the width of the kernel function of the system. These parameters determine the resultant structure of the model; therefore, it is important to determine their optimum values. In this paper, genetic algorithm (GA) was used to determine the optimum values of these parameters [7, 10, 14].

\section{Research Results}

All of the analyses were carried out using the information collected in the database of the dynamic resistance of reinforced concrete flyovers with a slab span system to the impacts of mining tremors. The database was prepared as a result of multiple numerical FEM analyses, in line with the procedure of resistance assessment according to [12].

In general, this procedure requires applying the response spectrum method for a multi-degree of freedom (MDOF) system in the FEM approach and adopting a standardized acceleration response spectra curve describing the seismic intensity for a given area:

$$
S_{a}=a_{g} \beta(T)=a_{g} S \begin{cases}{\left[1+\frac{T}{T_{B}}(2.5 \eta-1)\right]} & 0<T<T_{B} \\ 2.5 \eta & T_{B} \leq T \leq T_{C} \\ 2.5 \eta \frac{T_{C}}{T} & T_{C} \leq T \leq T_{D} \\ 2.5 \eta \frac{T_{C} T_{D}^{2}}{T^{3}} & T>T_{D}\end{cases}
$$

where:

$S_{a}$ - standardized acceleration response spectra adopted for the LGOM mining area according to [17] $\left[\mathrm{m} / \mathrm{s}^{2}\right]$,

$a_{g}$ - design acceleration of ground vibrations $\left[\mathrm{m} / \mathrm{s}^{2}\right]$,

$\stackrel{g}{T}$ - eigenmode period $[\mathrm{s}]$,

$T_{B}=0.30 \mathrm{~s}, T_{C}=0.80 \mathrm{~s}, T_{D}=1.3 \mathrm{~s}, S=1.5$, according to [17],

$\eta=\sqrt{\frac{10}{5+100 \xi}}, \xi=0.05-$ damping coefficient. 
According to [12], six conditions determining the resistance of the bridge object are considered in each of the analyzed cases:

1) the strength condition of the load-bearing capacity of the spans,

2) the condition of the load-bearing capacity of the fixed bearings and the bearings sliding in one direction (leading),

3) the condition of the contact between the support and the span,

4) the condition limiting the friction force for the sliding bearings,

5) the condition limiting the sliding of the sliding bearings,

6) the condition of the load-bearing capacity of the supports.

A determination of the limit values of the acceleration of ground vibrations $\left(a_{g, d o p, V}\left[\mathrm{~m} / \mathrm{s}^{2}\right]\right.$ and $\left.a_{g, d o p, H}\left[\mathrm{~m} / \mathrm{s}^{2}\right]\right)$ is made for each condition and consists of comparing the effects from the combinations adopted at the design stage of the structure with the effects from the seismic combination:

$$
E_{d}^{S E} \leq E_{d}^{P N}
$$

where:

$E_{d}^{S E}$ - design value of the effect of seismic impacts,

$E_{d}^{P N}$ - design value of the impact effect for a given combination of loads, adopted at the design stage.

Eventually, it included the permissible values of the components of the acceleration of ground vibrations $\left(a_{g, d o p, V}\left[\mathrm{~m} / \mathrm{s}^{2}\right]\right.$ and $\left.a_{g, d o p, H}\left[\mathrm{~m} / \mathrm{s}^{2}\right]\right)$ calculated for 3000 structures. The preceding stage during the analysis of each case recorded in the database was a random selection of geometrical and material properties in accordance with the guidelines contained in [5]. In this way, the diversity of information collected in the database was ensured.

\subsection{Building Artificial Neural Networks Approximating Permissible Values of Acceleration of Ground Vibrations $\left(a_{g, d o p, V}\right.$ and $\left.a_{g, d o p, H}\right)$}

When commencing with the construction of neural networks that are intended to approximate the permissible values of the acceleration of ground vibrations $\left(a_{g, d o p, V}\left[\mathrm{~m} / \mathrm{s}^{2}\right]\right.$ and $\left.a_{g, d o p, H}\left[\mathrm{~m} / \mathrm{s}^{2}\right]\right)$, the data set was divided into three sets: a training set $(60 \%=1800$ models $)$; a validation set $(20 \%=600$ models $)$; and a test set $(20 \%=600$ models). Then, a set of variables describing the geometrical and material properties as well as the mechanical parameters of the bearings was selected. The set of variables adopted for the analysis is demonstrated in Table 1.

The neural networks were constructed in the Matlab environment [6-8]. A three-layer feedforward neural network MLP (Multilayer Perceptron) with nonlinear activation functions in the neurons of the hidden layer was adopted as the 
target structure of the network. The analyses were conducted for all available learning methods [6]. In order to specify the target number of neurons in the hidden layer, an optimization using a genetic algorithm was performed for each adopted method. The optimization criterion was the error obtained for the predetermined test set.

Table 1. Geometrical and material variables adopted as input variables for ANN and SVM models

\begin{tabular}{|c|c|}
\hline Variable no. & Description of the variable \\
\hline Var.01 & Static scheme of the system \\
\hline Var.02 & Cantilevers (overhangs) [m] \\
\hline Var.03 & Number of spans \\
\hline Var.04 & Length of spans $[\mathrm{m}]$ \\
\hline Var.05 & Width of spans [m] \\
\hline Var.06 & Diversified height of spans \\
\hline Var.07 & Height of span $H$ - support zone [m] \\
\hline Var.08 & Height of span $h$ - middle zone $[\mathrm{m}]$ \\
\hline Var.09 & Length of cantilever/overhang [m] \\
\hline Var.10 & Number of support frames/wall pillars \\
\hline Var.11 & Number of pillars \\
\hline Var.12 & Width ( $y$ - perpendicular to the axis of the structure) of a single support/wall pillar [m] \\
\hline Var.13 & Width ( $x$ - parallel to the axis of the structure) of a single support/wall pillar [m] \\
\hline Var.14 & Number of bearings \\
\hline Var.15 & Height of the support frame lintel [m] \\
\hline Var.16 & Width of the support frame lintel $[\mathrm{m}]$ \\
\hline Var.17 & Height of supports/wall pillars [m] \\
\hline Var.18 & Modulus of elasticity of concrete of span slabs [GPa] \\
\hline Var.19 & Modulus of elasticity of concrete of support frame lintels [GPa] \\
\hline Var.20 & Modulus of elasticity of concrete of supports/wall pillars [GPa] \\
\hline Var.21 & Coefficient of friction of sliding bearings [-] \\
\hline
\end{tabular}

These analyses resulted in two neural networks, allowing for an approximation of the permissible values of the components of the acceleration of ground vibrations $\left(a_{g, d o p, V}\left[\mathrm{~m} / \mathrm{s}^{2}\right]\right.$ and $\left.a_{g, d o p, H}\left[\mathrm{~m} / \mathrm{s}^{2}\right]\right)$. Two measures were used to assess the models: Mean Squared Error (MSE) and the linear correlation coefficient between the results of the prediction and model values for predetermined training sets, validation sets, and test sets.

These models had the best properties in terms of fit and generalizability. The BFGS (Broyden-Fletcher-Goldfarb-Shanno [6]) algorithm turned out to be the best of all. Table 2 demonstrates the basic data on the structure of the created neuron networks. Table 3 presents the parameters that allowed for the assessment of the networks for the fit quality of the prediction to model data and its generalizability. 
Table 2. Basic characteristics determining structure of created neural networks

\begin{tabular}{|c|c|c||}
\hline $\begin{array}{c}\text { Number of neurons } \\
\text { in hidden layer }\end{array}$ & $\begin{array}{c}\text { Activation functions } \\
\text { of neurons in hidden layer }\end{array}$ & $\begin{array}{c}\text { Applied learning } \\
\text { algorithm }\end{array}$ \\
\hline \hline \multicolumn{3}{|c||}{ Neural network for approximation $a_{g, d o p, V}$} \\
\hline 96 & Logistic function & BFGS \\
\hline 93 & Neural network for approximation $a_{g, d o p, H}$ \\
\hline \multicolumn{3}{|c|}{ Tanh function } \\
\hline
\end{tabular}

Table 3. Assessment of fit quality and generalizability of the created neural networks

\begin{tabular}{||c|c|c|c|c|c||}
\hline \multicolumn{3}{|c|}{ MSE Error } & \multicolumn{3}{c|}{$\begin{array}{c}\text { The value of linear correlation coefficient } \mathbf{R} \\
\text { between pattern data and prediction of each } \\
\text { model }\end{array}$} \\
\hline \hline training set & validation set & test set & training set & validation set & test set \\
\hline \multicolumn{7}{|c|}{ Neural network for approximation $a_{g, d o p, V}$} & 0.98 \\
\hline 0.0010 & 0.0022 & 0.0027 & 0.99 & 0.99 \\
\hline 0.0048 & 0.0067 & Neural network for approximation $a_{g, d o p, H}$ & 0.73 \\
\hline
\end{tabular}

Table 3 demonstrates the values of the errors and of the linear correlation coefficient between the prediction of the created neural networks and the model data. Therefore, it is possible to note that:

- the neural network created to approximate a permissible vertical component of the acceleration of ground vibrations $a_{g, d o p, V}\left[\mathrm{~m} / \mathrm{s}^{2}\right]$ has a very high degree of prediction fit to the model data for all sets included in the learning and testing stages. In addition, this model does not exhibit any overfitting, as evidenced by the comparable values of the Mean Squared Errors and correlation coefficient calculated for all of the analyzed sets;

- the neural network approximating a horizontal component of the permissible acceleration of ground vibrations $a_{g, d o p, H}\left[\mathrm{~m} / \mathrm{s}^{2}\right]$ has satisfactory properties in the sense of a prediction fit to the model data; it does not exhibit any signs of overfitting either, proving that it has achieved good generalizability in the learning process;

- both models were created based on a comparable number of neurons in the hidden layer (c.f. Tab. 3). The numbers of neurons referenced to the total number of models from the training set (1800) provide an additional basis for assessing the level of generalization of the created models as very good. 


\subsection{Building SVM models approximating permissible values of acceleration of ground vibrations $\left(a_{g, d o p, V}\right.$ and $\left.a_{g, d o p, H}\right)$}

Building SVR models was based on the separation of two sets: a training set and a test set (the latter of which was not used during the learning stage). It was predetermined that the training set would represent $70 \%$ of the total number of models contained in the database, and the rest were assigned to the test set.

The next stage involved the optimal selection of parameters $C, \varepsilon$, and $\sigma$. This was the most-important stage in the study, as when having the optimum set of these parameters, the process of building the structure of the SVR model is reduced to solving a quadratic optimization problem in Lagrange multipliers, which is significantly less entangled than neural network learning. In order to determine the optimal values of parameters $C, \varepsilon$, and $\sigma$, a genetic algorithm was used for which the criterion was the value of the error function from a five-fold cross-validation [10].

In order to identify the optimal structures of the SVR models approximating the limit values of the acceleration of ground vibrations $\left(a_{g, d o p, V}\left[\mathrm{~m} / \mathrm{s}^{2}\right]\right.$ and $\left.a_{g, d o p, H}\left[\mathrm{~m} / \mathrm{s}^{2}\right]\right)$, this procedure was performed twice. The obtained results describing the basic data concerning the structures of the individual models are presented in Table 4. Table 5 demonstrates the assessment results in the context of fit quality and generalizability.

Table 4. Parameters defining structures of created SVR models

\begin{tabular}{||l|c|c|c|c||}
\hline \hline Created SVR models & $\begin{array}{c}\text { Number of } \\
\text { support vectors }\end{array}$ & $\begin{array}{c}\text { Value of } \\
\text { regularization } \\
\text { constant } C\end{array}$ & $\begin{array}{c}\text { Tolerance band } \\
\text { width } \varepsilon\end{array}$ & $\begin{array}{c}\text { Width of kernel } \\
\text { function } \sigma\end{array}$ \\
\hline \hline $\begin{array}{l}\text { SVM model for } \\
\text { approximation } a_{g, d o p, V}\end{array}$ & 1594 & 14.86 & 0.0055 & 4.68 \\
\hline $\begin{array}{l}\text { SVM model for } \\
\text { approximation } a_{g, d o p, H}\end{array}$ & 1009 & 9.17 & 0.0739 & 8.97 \\
\hline
\end{tabular}

Table 5. Assessment of fit quality and generalizability of created SVR models

\begin{tabular}{||l|c|c|c|c||}
\hline \multirow{2}{*}{ Created SVR models } & \multicolumn{2}{|c|}{ MSE Error } & \multicolumn{2}{c|}{$\begin{array}{c}\text { Value of linear correlation coefficient } \\
\text { R } \\
\text { between pattern data } \\
\text { and prediction of each model }\end{array}$} \\
\cline { 2 - 5 } & training set & test set & training set & test set \\
\hline \hline $\begin{array}{l}\text { SVM model for } \\
\text { approximation } a_{g, d o p, V}\end{array}$ & 0.0054 & 0.0298 & 0.98 & 0.93 \\
\hline $\begin{array}{l}\text { SVM model for } \\
\text { approximation } a_{g, d o p, H}\end{array}$ & 0.0109 & 0.0162 & 0.83 & 0.73 \\
\hline
\end{tabular}


The values of the errors and of the coefficient of linear correlation between the prediction of the created SVR models and the model data (demonstrated in Table 5) prove that:

- the SVR model created to approximate the permissible vertical component of the acceleration of ground vibrations $a_{g, d o p, V}\left[\mathrm{~m} / \mathrm{s}^{2}\right]$ is characterized by a high degree of prediction fit to the model data for all sets taken into account in the learning and testing stages; this model, however, exhibits a small degree of overfitting, as evidenced by an MSE value for the test set that is greater than for the training set;

- the SVR model approximating the horizontal component of the permissible acceleration of ground vibrations $a_{g, d o p, H}\left[\mathrm{~m} / \mathrm{s}^{2}\right]$ obtained satisfactory properties, both in the sense of the prediction fit to the model data as well as generalization;

- analyzing the number of supporting vectors (c.f. Tab. 4) that directly translate into the complexity of the SVR model structures, it can be noticed that, in the case of the SVR model created for the approximation of component $a_{g, d o p, H}\left[\mathrm{~m} / \mathrm{s}^{2}\right]$, the number of support vectors is significantly smaller than for the model approximating component $a_{g, d o p, H}\left[\mathrm{~m} / \mathrm{s}^{2}\right]$; this is additional information to confirm the better generalizability of the model approximating component $a_{g, d o p, H}\left[\mathrm{~m} / \mathrm{s}^{2}\right]$ compared to the SVR model created to approximate horizontal component $a_{g, d o p, V}\left[\mathrm{~m} / \mathrm{s}^{2}\right]$, for which a higher degree of fit yet a worse generalizability of the acquired knowledge was obtained.

\section{Summary and Conclusions}

The results of the performed analyses presented in this paper demonstrate that the use of Machine Learning methods can be an alternative to numerical Finite Element Analysis. This particularly applies to the case when it is necessary to determine the dynamic resistance of a large number of structures.

According to the author, application of these methods will increase the effectiveness of assessing the resistance of bridge structures to the impact of mining tremors by reducing the number of calculation procedures required for such analyses (cf. Fig. 1). It will make analyzing the cases easier where the information on the material parameters is uncertain, and it can contribute considerably to Geographic Information Systems (GIS) by supplying data on the resistance of bridge structures in a specific area.

The obtained results prove that both the Artificial Neural Networks and the method of supporting vectors can be used as numerical tools to approximate the permissible components of the acceleration of ground vibrations $\left(a_{g, d o p, V}\left[\mathrm{~m} / \mathrm{s}^{2}\right]\right.$ and $\left.a_{g, d o p, H}\left[\mathrm{~m} / \mathrm{s}^{2}\right]\right)$, defining the dynamic resistance of bridge structures to the impact of mining tremors. The presented results demonstrate that Artificial Neural Networks are a better solution to this problem. 
The approach applied here can be transferred to other types of existing structures; however, this requires us to create a sufficient number of databases to allow for the learning and testing of the systems that belong to the group of machine learning methods.

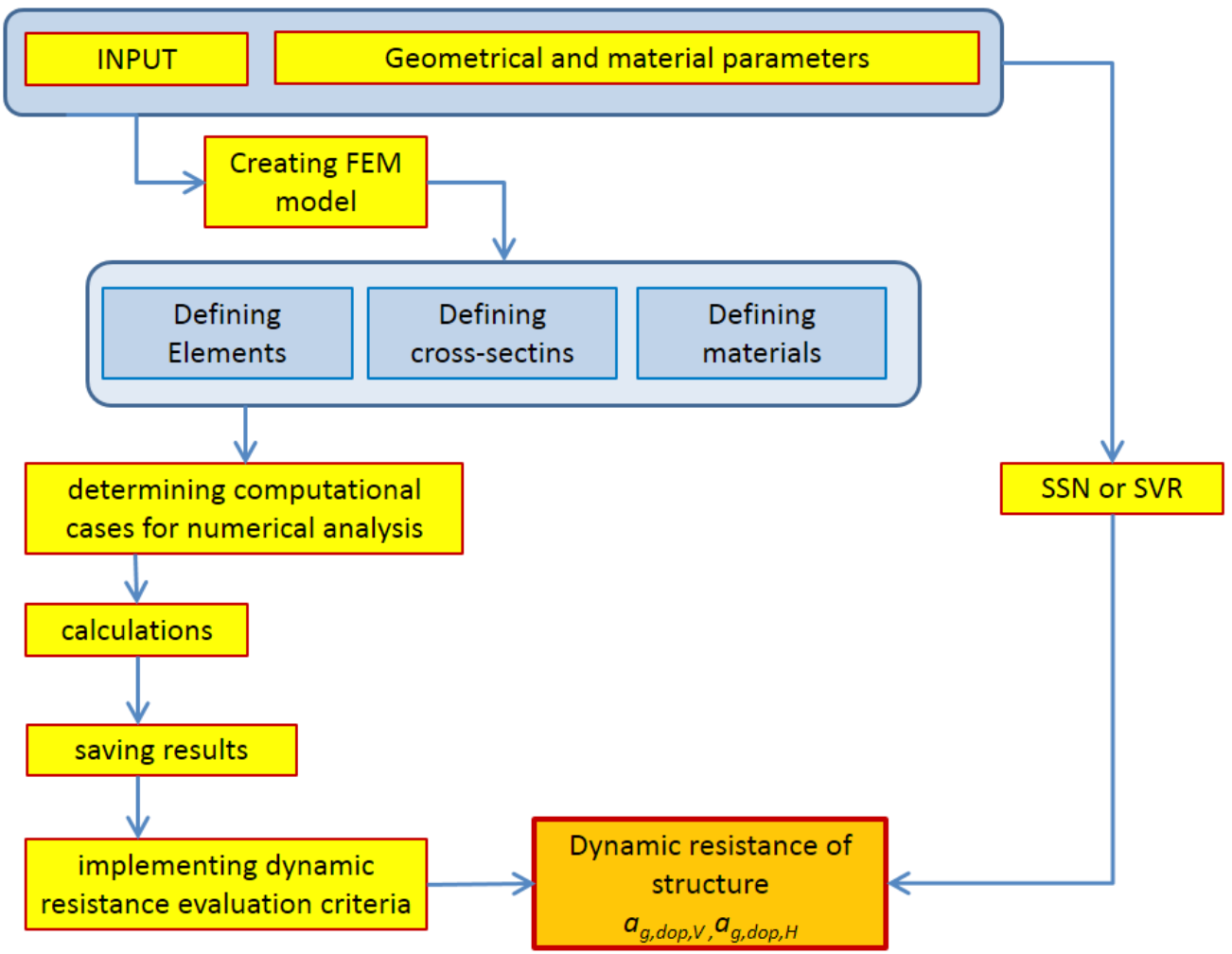

Fig. 1. Comparison of procedures of determining dynamic resistance using FEM numerical approach and machine learning methods

\section{References}

[1] Dhar S., Cherkassky V.: Universum Learning for SVM Regression. arXiv preprint arXiv:1605.08497. 2016.

[2] Firek K.: Analysis of damage to masonry multi-storey building structures located in the mining area using data mining techniques. Polish Journal of Environmental Studies, vol. 25, no. 5A, 2016, pp. 37-41.

[3] Kinash R.: Metody oceny niezawodności konstrukcji budowlanych przy niepetnych parametrach. Górnictwo i Geoinżynieria, R. 32, z. 2, 2008, pp. 187-195. 
[4] Kuźniar K., Tatara T.: Drgania pochodzenia górniczego gruntu i fundamentu budynku w ocenie ich szkodliwości. Zeszyty Naukowe Instytutu Gospodarki Surowcami Mineralnymi i Energią PAN, nr 94, 2016, pp. 5-14.

[5] Madaj A., Wołowicki W.: Projektowanie mostów betonowych. Wydawnictwa Komunikacji i Łączności, Warszawa 2010.

[6] MATLAB and Neural Networks Toolbox 2016a. The MathWorks Inc., Natick, MA, 2000.

[7] MATLAB and Optimization Toolbox 2016a. The MathWorks Inc., Natick, MA, 2000.

[8] MATLAB and Statistics and Machine Learning Toolbox 2016a. The MathWorks Inc., Natick, MA, 2000.

[9] Osowski S.: Sieci neuronowe do przetwarzania informacji. Oficyna Wydawnicza Politechniki Warszawskiej, Warszawa 2013.

[10] Rusek J.: Modelowanie stopnia zużycia technicznego budynków na terenach górniczych z wykorzystaniem wybranych metod sztucznej inteligencji. Wydawnictwa AGH, Kraków 2013.

[11] Rusek J.: Procedure of building and analysis of the information database of the resistance of existing bridge structures to mining tremors. Geomatics and Environmental Engineering, vol. 11, no. 4, 2017, pp. 111-123.

[12] Rusek J.: A proposal for an assessment method of the dynamic resistance of concrete slab viaducts subjected to impact loads caused by mining tremors. Czasopismo Inżynierii Lądowej, Środowiska i Architektury, t. 34, z. 64, nr 1, 2017, pp. 469-485.

[13] Samarasinghe S.: Neural networks for applied sciences and engineering: from fundamentals to complex pattern recognition. CRC Press, 2016.

[14] Syarif I., Prugel-Bennett A., Wills G.: SVM Parameter Optimization using Grid Searchand Genetic Algorithm to Improve Classification Performance. TELKOMNIKA (Telecommunication Computing Electronics and Control), vol. 14, no. 4, 2016, pp. 1502-1509.

[15] Witten I.H., Frank E., Hall M.A., Pal C.J.: Data Mining: Practical machine learning tools and techniques. Morgan Kaufmann, 2016.

[16] Vapnik V., Izmailov R.: Knowledge transfer in SVM and neural networks. Annals of Mathematics and Artificial Intelligence, vol. 81, Issue 1-2, pp. 3-19.

[17] Zembaty Z., Kokot S.: Adaptacja sejsmicznych norm projektowania konstrukcji do ujęcia wptywu wstrząsów górniczych na budowle. Przegląd Górniczy, t. 70, nr 6,2014 , pp. 72-77.

[18] Zembaty Z.: Analiza porównawcza wstrzasów górniczych LGOM i słabych trzęsień ziemi. [in:] Problemy projektowania i ochrony obiektów budowlanych na terenach górniczych: II konferencja naukowo-techniczna, Rudy Raciborskie 27-28 maja 2004 r., ITB, Warszawa, pp. 171-181. 


\section{Metody uczenia maszynowego w ocenie odporności dynamicznej istniejących obiektów mostowych poddanych wstrząsom górniczym}

Streszczenie: W pracy przedstawiono wyniki badań, których celem było utworzenie modelu pozwalającego na określenie odporności istniejących obiektów mostowych na wpływy wstrząsów górniczych. Podstawą do analiz była utworzona przez autora baza danych o odporności dynamicznej żelbetowych obiektów mostowych poddanych wymuszeniu sejsmicznemu charakterystycznemu dla terenu Legnicko-Głogowskiego Okręgu Miedziowego (LGOM). Odporność dynamiczna każdego obiektu w bazie danych została wyrażona w postaci granicznych wartości przyspieszeń drgań gruntu, jakie dana konstrukcja może przejąć bez zagrożenia bezpieczeństwa. Badania przeprowadzono, wykorzystując metodę Support Vector Machine (SVM) w ujęciu regresyjnym (SVR - Support Vector Regression) oraz sztuczne sieci neuronowe (ANN - Artificial Neural Network). Utworzone w ten sposób modele porównano w aspekcie jakości predykcji oraz uogólniania nabytej wiedzy. Pozwoliło to na wytypowanie metody najbardziej efektywnej pod względem oceny odporności dynamicznej istniejących obiektów mostów.

\section{Słowa}

kluczowe: dynamika budowli, uczenie maszynowe, sztuczne sieci neuronowe, SVM, wstrząsy górnicze, odporność dynamiczna, mosty 